\title{
Memaknai kebahagiaan: Analisis Kualitatif pada Komunitas Punker di Kota Banda Aceh
}

\section{To Pursue Happiness: A Qualitative Analysis Of Punker Community In Banda Aceh City}

\author{
M. Reza Rifki ${ }^{*}$, Fadhila Tunnissa ${ }^{1}$, Rini Agustina ${ }^{1}$, Rita Muliyani ${ }^{1}$, Aqil Albanna ${ }^{1}$, Ida Fitria ${ }^{1}$ \\ ${ }^{1}$ Fakultas Psikologi Universitas Islam Negeri Ar-Raniry, Banda Aceh \\ *Reza26rifki@gmail.com
}

\begin{abstract}
Abstrak
Fenomena Punk beberapa tahun terakhir sudah mulai muncul ke permukaan khususnya di daerah Kota Banda Aceh yang bersyariat Islam, namun pertumbuhan Punkers dari tahun ketahun semakin meningkat, baik dari warga pendatang maupun warga Aceh. Penelitian ini bertujuan untuk mendiskripsikan kesejahteraan subjektif dari anak Punk dengan fokus mengungkap makna kebahagiaan dan dilema hidup dalam komunitas Punk. Partisipan dalam penelitian ini adalah 6 orang anak Punk yang kemudian terlibat dalam wawancara mendalam dan FGD di Peunayong, Banda Aceh. Hasil analisa kualitatif penelitian ini menggambarkan beberapa alasan mereka bertahan dalam komunitas Punk, diantaranya kebersamaan dan kekeluargaan yang dirasakan antara sesama anggota komunitas ini begitu besar. Anak Punk memaknai kebahagiaan sebagai kebebasan dan mendapatkan kenyamanan dalam kelompok keluarga baru. Makna kebahagaiaan bagi mereka adalah kebebasan, harga diri, teman, kekeluargaan, dan traveling. Terdapat hal penting yang menjadi catatan diantaranya pergaulan mereka yang cenderung tidak sehat, seperti pergaulan bebas, menggunakan narkoba dan pakaian yang tidak sesuai dengan anjuran seorang muslim.Penelitian ini berkontribusi untuk mengungkap makna kebahagiaan bagi remaja kelompok Punk dengan gambaran aspek-aspek kebahagiaan subjektif dan dilema kehidupan punkers dalam dimensi yang lebih lengkap. Implikasi dari penelitian ini diharapkan dapat menjadi masukan dalam pembinaan remaja punk.
\end{abstract}

Kata kunci: Komunitas Punk, Kebahagiaan, Banda Aceh

\begin{abstract}
Punk phenomenon has started emerge in Banda Aceh City since last few years, as the city under Sharia law but the growth of Punkers is keep incresing knowday, both from immigrants and Acehnese. This study aims to describe the well-being of Punkers. Further, researchers have focused on the meaning of happiness through the Punkers perspective. The participants of this study are 6 punkers who had been interviewed and involved in Focus Group Discussion. This study has been conducted in Banda Aceh City, Penayong with qualitative data analysis approach. The result of this study has described that one of the reasons why Punkers may feel settle with their community is togetherness and the feeling to own a comfortable family. The meaning of happiness from punkers' perspective is a freedom and new family group. The meaning of happiness for them is freedom, selfrespect, friendships, kinship, and traveling. Its importance to be noted about their relationships that tend to be unhealthy such as promiscuity, using drugs and clothes that are not in accordance to the recommendation as a muslim. This study has a great contribution to disclose the sensitive issue of punkers' phenomenon and reported the deep feeling of their life regarding to well-being, and described further dimension of happiness and the dilemma of punkers. The Implication of this sudy can be used in guidance the punkers.
\end{abstract}

Key words: Punkers, Happiness, Banda Aceh 


\section{Pendahuluan}

Kata Punk berasal dari bahasa Inggris yang merupakan singkatan dari "publik united not kingdom". Artinya adalah kesatuan masyarakat di luar kerajaan. Punk masuk di Indonesia pada akhir 80-an, perkembangan pesat terjadi pada awal pertengahan tahun 90 -an. Pada waktu itu Punk merupakan sebuah subkultur yang dinamis dan eksperimental dengan kesan-kesan pemberontakan visual tapi tidak bisa dianggap sebuah budaya berlawanan yang bersatu dan berkerja sama supaya tujuan tercapai (Annisa dkk, 2015).

Punk awalnya lahir di London, Inggris. Pada tahun 1960-an sebagai wujud dari bentuk perlawanan yang di pelopori oleh para kaum muda. Komunitas Punk merupakan suatu wadah perkumpulan para kaum muda yang mengutamakan kebebasan, tanpa tekanan dan tuntutantuntutan dari atasan. Mereka yang bergabung dalam komunitas Punk mengakui bahwa dengan bergabungnya mereka dalam komunitas tersebut mereka bisa mendapatkan self-esteem yang tinggi, dikarenakan mereka saling berbagi, bertukar pikiran, dan mereka mampu saling menghargai satu sama lain (Annisa, 2015).

Mereka yang bergabung dengan Punkers memiliki perbedaan dengan masyarakat awam. Perbedaan ini terlihat dari gaya berpakaian mereka yang serba meniru kebarat-baratan dengan rambut mohawk ala suku Indian atau diwarna-warnai, baju lusuh, anti kemapanan, kaum dari kelas rendah dan berpakaian compang-camping (Sari dkk, 2008).

Komunitas Punkers memiliki budaya komunitas tersendiri. Seperti ketika berkumpul bersama para anggota Punkers selalu membicarakan tentang kebebasan, otoritarian pemerintah, dan kemanusian. Oleh karena itu dalam komunitas tidak ada yang memimpin. Hal tersebutlah yang kemudian membuat Punkers merasa mampu untuk menjadi pribadi yang bebas berekspresi serta berinspirasi. Mereka menganggap tidak memerlukan seorang pemimpin karena hanya membutuhkan teman-teman yang selalu bersedia untuk bersama mereka dalam kondisi apapun, untuk saling bertukar pikiran serta untuk saling menghargai (Petrus \& Berek, 2014).

Awal mula pengaruh Punk di Indonesia dari proses modernisasi dan globalisasi di dunia. Modernisasi adalah suatu proses transformasi dari suatu arah perubahan ke arah yang lebih maju atau meningkat dalam berbagai aspek dalam kehidupan masyarakat dan globalisasi adalah proses masuknya ke ruang lingkup dunia (Elly \& Rosana, 2011).

Komunitas Punkers di Indonesia dengan Punk di barat memiliki beberapa perbedaan. Perbedaan tersebut terlihat jelas dari cara berinteraksi, mengelola kelompok, motif bergabung dan perspektif. Salah satu contoh pada komunitas Punkers di Indonesia, diantaranya faktor bergabung karena putus sekolah dan keadaan ekonomi, tetapi di barat bergabungnya mereka dalam komunitas punk dengan status berpendidikan. Selain itu Punkers di western (barat) bergabung untuk mengeritik kebijakan-kebijakan pemerintahan yang tidak mendukung rakyat, tetapidi Indonesia Punkers masuk adalah mereka lari dari permasalahan sosial seperti kriminal, masalah keluarga, pendidikan dan ekonomi (Annisa dkk, 2015).

Hal yang sama juga terjadi di Aceh. Sebagian besar dari punkers tidak menyelesaikan pendidikan, masalah ekonomi dan keluarga. Hal itu menyebabkan punkers memiliki gaya hidup dan philosopi yang berbeda sehingga hal ini menyebabkan adanya kesenjangan kebudayaan antara masyarakat Aceh yang berbudaya Islami dengan punkers, lalu menyebabkan masyarakat merasa tidak nyaman dan memandang sinis keberadaan punkers (Annisa dkk, 2015).

Pandangan masyarakat yang merasa tidak nyaman dan memandang sinis keberadaan punkers menyebabkan punkers di Aceh merasa tertekan oleh masyarakat. Menurut penjelasan yang dikutip oleh beberapa anggota Punker yang sudah lama bergabung lalu memutuskan tinggal di Banda Aceh menyatakan bahwa keberadaan komunitas Punk di Aceh hingga saat ini belum mampu mendapatkan pandangan yang positif dari masyarakat setempat, apalagi dari pemerintah (Setyad, 2017).

Pemerintah sering kali melakukan razia terhadap aktifitas Punkers. Seperti pembubaran konser musik di Taman Budaya Banda Aceh oleh Punkers. Sebanyak 65 orang punkers ditangkap oleh Tim Razia. (Setyad, 2017). Walaupun demikian menurut salah satu punkers di Banda Aceh mereka mengatakan bahwa tetap bertahan dan tetap menikmati setiap kegiatan yang mereka lakukan dengan bahagia (Larsson, 2016).

Kebahagiaan bagi komunitas punkers merupakan hal yang esensial. Hal tesebut merupakan tujuan utama dari punkers untuk bergabung. Menurut Seligman (2009) seseorang melakukan suatu 
aktifitas merupakan proses dari mencari kebahagiaan, baik hal tersebut dilakukan secara sengaja ataupun tidak sengaja. Teori behavior juga menjelaskan proses adaptasi untuk dapat bertahan hidup. Ketika makhluk hidup mendapatkan kesulitan dalam hidupnya, atau disebut stimulus yang negatif. Maka mahluk hidup tersebut akan bereaksi terhadap stimulus dengan mencoba untuk fight or flight (Kalat, 2010).

Femonena ini sangat menarik terjadi di Banda Aceh dimana komunitas punkers menetap walaupun kerap kali mengalami tekanan dari masyarakat, pemerintah daerah dan penerapan syariat Islam. Hal ini dikarenakan Punkers memiliki filosofis hidup bebas. Ini tercemin bagaimana mereka mengekspresikan dengan memakai baju yang compang-camping, tidur dimana saja, dan tidak terikat dengan apapun, sedangkan penerapan Syariah Islam di Banda Aceh mengharuskan untuk semua orang untuk berpakaian dengan cara tertentu dan hidup dengan gaya tertentu. Juga ditambah banyak kasus yang terjadi pada mereka berupa berulang kali ditangkap oleh WH (Wilayatul Hisbah) lalu dimasukkan ke dalam kampung reedukasi (Fariza, 2016).

Pada penelitian ini peneliti menggunakan teori Martin Seligman (2009) yang dijelaskan dalam bukunya yang berjudul Flourish: A Visionary New Understanding of Happiness and Wellbeing. Juga teori Seligman sendiri lebih sejalan dengan tujuan penelitian yaitu ingin mengungkapkan apa itu kebahagiaan dalam pandangan subjektif punkers, aspek dalam teori lebih komprehensif dalam mengungkapkan aspek kebahagiaan pada punkers dan juga teori Martin Seligman minim bias budaya karena pengambilan sampel dalam penelitiannya tidak hanya diambil di barat saja tetapi di seluruh dunia sehingga bersifat universal.

Penelitian ini berkontribusi untuk mengungkap makna kebahagiaan bagi kehidupan kelompok Punk yang tinggal di Kota Banda Aceh, bagaimana sistem pemerintahan syariat islam mempengaruhi kebahagiaan subjektif punkers, dilema kehidupan punkers dalam dimensi yang lebih lengkap dan isu sensitif bagi kelompok Punk yang berada di Kota Banda Aceh yang bersyariat Islam, dikarenakan selama ini sedikit penelitian tentang psikologi positif yang berfokus pada kelompok minoritas yang hidup di lingkungan yang berlawanan dengan nilai mereka. Sehingga diharapkan dengan penelitian ini dapat membingkai dengan baik apa itu kebahagiaan pada kelompok minoritas tersebut dan dapat memahami mereka lebih baik. Hal ini diharapkan dapat menjadi pertimbangan dalam pembinaan remaja punk sebagai upaya untuk mengembangkan kebahagiaan mereka dengan tetap menjalankan syariat islam sesuai dengan visi dan misi Kota Banda Aceh yang menerapkan Syariat Islam.

\section{Metode Penelitian}

Penelitian ini menggunakan pendekatan kualitatif dengan jenis penelitian deskriptif. Penelitian ini dilakukan di Pasar Penayong, kota Banda Aceh, Aceh. Jumlah sampel adalah 6 orang, 3 orang yang diwawancara secara mendalam, lalu dilajutkan dengan Focus group Discussion dengan jumlah 6 orang. Wawancara dilaksanakan pada tanggal 17 November 2017 dan lokasi wawancara dilakukan di emperan ruko. Teknik pengumpulan data dalam penelitian ini menggunakan metode wawancara dan observasi secara langsung dan responden dipilih dengan menggunakan purposive sampling.

Interview dilakukan secara terpisah dengan dua orang untuk wawancara pertama dan dilanjutkan satu orang pada minggu selanjutnya lalu dilanjutkan Focus Group Discussion dengan 6 orang. Menggunakan teori Seligman yang mendefinisikan bahwa Happiness adalah keadaan seseorang menikmati suatu keadaan atau perasaan senang dan tentram baik lahir maupun batin dan merupakan hal yang mendasar yang dibutuhkan oleh seorang individu. Alat ukut enam dimensi pengkuran menggunakan teori Seligman dkk (2009) yaitu relasi positif, optimistik, emosi positif, keterlibatan penuh, ketahanan diri dan penemuan makna. Relasi positif adalah relasi yang tercipta apabila individu mendapatkan dukungan orang lain sehingga mampu mengembangkan self-esteem, mampu memecahkan masalah, serta individu sehat secara fisik. Keterlibatan penuh adalah mengikuti berbagai aktivitas-aktivitas bersama keluarga baik fisik, hati dan pikiran. Penemuan makna dalam keseharian adalah bagaimana individu berfikir positif ketika melakukan aktivitas sehari-hari dengan terlibat secara penuh terhadap aktivitas yang dilakukannya. Optimis adalah sikap pikiran positif yang dapat memberikan keuntungan dalam jajaran yang luas seperti, kesehatan, umur panjang, keberhasilan pekerjaan dan memperoleh nilai yang tinggi dalam prestasi. 
Ketahanan diri yang adalah kemampuan seseorang untuk bangkit dari peristiwa yang tidak menyenangkan.

Enam aspek tersebut kemudian dikembangkan dengan membuat pertanyaan yang terdiri dari 12 pertanyaan berdasarkan enam aspek. Setelah melakukan collecting data di lapangan lalu dilanjutkan dengan proses codding yang hasilnya mengerucut menjadi adalah kepuasan hidup, hidup tidak sesuai harapan, emosi negatif, emosi positif, pengalaman yang sulit dilupakan, pengalaman masa lalu yang negatif, alasan bergabung, harapan, dan kebabasan yang dibantu dengan Microsoft Excel 2010. Kemudian dipilih lagi berdasarkan codding yang muncul paling sering, lalu dipilih kata-kata yang sering muncul pada terkait yang berhubungan dengan kebahagian. Setelah itu dianalisis sesuai dengan teori happiness dari Seligman (2009), serta dengan tambahan data observasi yang berdasarkan fakta lalu kemudian disimpulkan.

\section{Hasil Penelitian}

Berdasarkan dari data koding didapat delapan kata-kata yang sering muncul dari wawancara. Kedelapan kata-kata tersebut diantaranya adalah kepuasan hidup, hidup tidak sesuai harapan, emosi negatif, emosi positif, pengalaman yang sulit dilupakan, pengalaman masa lalu yang negatif, alasan bergabung, harapan, dan kebebasan.

Pada delapan koding kata tersebut peneliti memilih yang mana kata-kata paling banyak mencerminkan kebahagiaan dan pemaknaan hidup Punkers berdasarkan teori Martin Seligman. Didapat bahwa Kebahagian dan Pemaknaan hidup dari seorang punkers adalah kebebasan, harga diri, teman, kekeluargaan dan Traveling.

Dari hasil yang telah didapat bahwa DN hanya menempuh pendidikan tingkat sekolah dasar. DN masuk ke komunitas Punk karena tidak ada yang dapat membantu ia dalam menyelesaikan masalah hidupnya ditambah lagi ia ditolak oleh masyarakat. Dalam lingkungan Punk ia mendapat rasa hormat dan kasih sayang dimana pada situasi kehidupan sebelumnya ia tidak mendapatkan dukungan dan ditolak oleh lingkungan hidupnya, sehingga berkali-kali DN menyatakan bahwa kebahagiaan adalah bersama teman-teman Punk. Seperti kalimat dibawah ini:

"Nyaman... aku punya kawan-kawan yang mempunyai solidaritas yang tinggi. Contohnya seperti aku disini, ada yang menerimaku, memberitahuku, yang menjamuku, menemaniku”. (DN, 2017. No.17)

"Kita punya banyak kawan". (DN, 2017. No.22) No.19)

"Walaupun kita tidak mempunyai keluarga sedarah, tapi kita belajar sedarah". (DN, 2017.

Pada kesimpulan subjek kedua yang bernama Ibo, peneliti mendapat gambaran bahwa Ibo memutuskan untuk tidak melanjutkan pendidikannya lagi disebuah Universitas dan akhirnya Ibo memilih bergabung kedalam komunitas Punk dengan alasan karena ia membenci sistem pemerintahan yang ada. Kutipan langsung dari subjek menegenai hal ini adalah: "Alasannya sih enggak ada apa-apa. Cuma karena benci aja sama sistem pemerintah" (Ibo, 2017. No 129).

Menurutnya ada beberapa pihak yang menjalankan tugas tidak sesuai dengan ketentuan yang ada. Misalnya seperti kejadian saat mereka di razia dan ditangkap dengan alasan untuk dibina, akan tetapi mereka malah mendapatkan perlakuan kasar. Seperti kutipan langsung dari subjek:

"Tapi pas ketangkap, orangtu kok main hakim sendiri kekgitu, kayak hakim rimba main pukul main tunjang. Sementarakan undang-undang kitakan semua punya HAM jadi kenapa harus melakukan tindakan kasar kayak gitu. Apakah kawan-kawan saya ni bukan manuisa” (Ibo, 2017. No. 47).

Dari alasan yang telah diungkapkan oleh subjek, peneliti melihat bahwa alasan tersebut digunakan untuk menutupi alasan yang sebenarnya. Yaitu, subjek pasti mempunyai masalah dalam keluarganya sehingga subjek tidak mendapatkan kebahagiaan dan kehangatan dari keluarga, akhirnya subjek mencari suatu wadah yang menurutnya mampu memberikan kebahagiaan dan kehangatan yang tidak ia dapatkan dari keluarganya. Oleh karena itu, ia memilih untuk bergabung dalam komunitas Punk.

Kesimpulan subjek ketiga (AD), berada di komunitas punk membuatnya senang, asik dan sangat bahagia bersama teman-teman tanpa adanya tekanan dari pihak lain layaknya seorang 
atasan terhadap bawahan. Menurutnya, kebahagiaan itu tidak harus selalu didapat dengan kekayaan, hal ini dikutip langsung dari kalimat subjek:

"gak mesti kaya, bahagia itu kita cukup dengan ada aja, berkecukupan, gak menganggu orang lain, berdiri atas kaki kita sendiri”(DN, 2017. No.8)

"orang kaya pun engga bahagia sebenarnya dalam hati dia itu" (DN, 2017. No.15).

Bagi AD kebahagiaan adalah kita dapat merasa cukup dengan yang kita miliki dan kita memperolehnya atas dasar kaki kita sendiri tanpa menganggu orang lain. Meskipun demikian untuk kepuasan dalam diri AD, ia belum mendapatkan satu batu loncatan sebagai suatu usaha atas karya AD. Dikutip dari "belum pas kali karna kenapaa..belum ada satu..satu batu loncatan aku untuk berdiri kuat” (DN, 2017. No. 27).

\section{Pembahasan}

Penelitian ini mengungkapkan bahwa kebahagian di dalam komunitas Punkers adalah kebahagian layaknya dalam sebuah keluarga. Meskipun pada kenyataannya, keberadaan komunitas Punk tidak mendapat pandangan yang cukup baik dalam masyarakat dan dipandang secara negatif. Namun tidak membuat anggota Punkers berkurang setiap tahun. Mereka memilih bergabung untuk menjadi anak Punk bukan karena adanya unsur paksaan atau sekedar ikutikutan saja.

Mereka memaknai kebahagaiaannya sebagai kebebasan, harga diri, teman, kekeluargaan, dan traveling. Lebih lanjut lagi dapat dilihat pada Gambar 1.

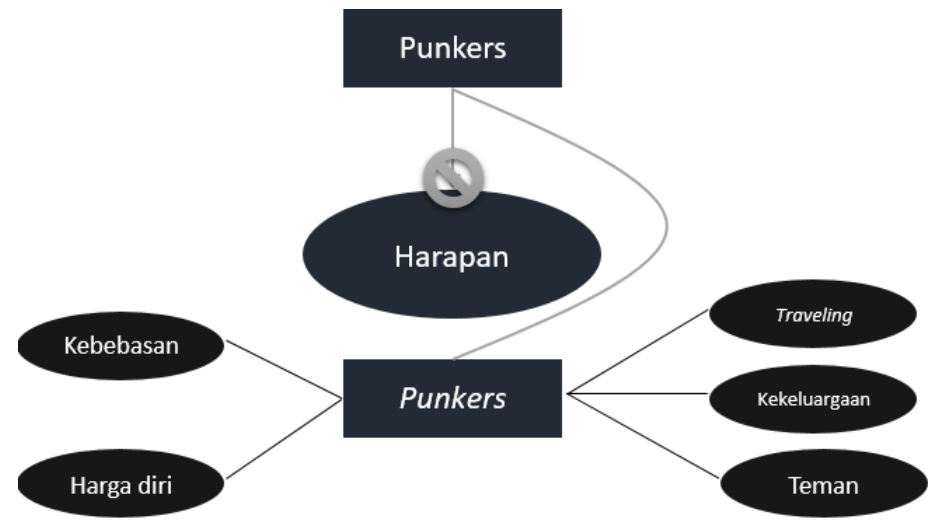

Gambar 1. Dinamika Kebahagiaan Punkers

Menurut Seligman dan Diener (2009), happiness atau kebahagiaan seseorang terdiri dari emosi positif, seperti kenyamanan dan kegembiraan, maupun aktifitas yang positif yang tidak memenuhi komponen emosi apapun, seperti absorbsi dan keterlibatan, semuanya didapatkan secara utuh dalam keluarga. Seligman menjelaskan bahwa emosi positif dalam seseorang sangat penting dalam kepusaan dalam hidup. Seseorang yang sehat mental adalah seseorang yang memiliki emosi positif dalam kehidupan sehari-hari. Hal tersebut berlaku untuk seluruh umat manusia sekalipun, tidak memandang etnis, ras, budaya, dan agama. Demikian pula kebahagiaan yang dirasakan oleh remaja punkers ini

Kebahagiaan tersebut juga bersesuaian dengan penelitian sebelumnya yang dilakukan oleh Argo dkk (2014) yang menyatakan bahwa makna dari pertemanan didalam komunitas Punk adalah kebersamaan yang membuat anak Punk memaknai temannya sebagai saudara yang merupakan tempat untuk bertukar informasi dan saling membantu, ini terjadi karena mereka berteman berdasarkan kebersamaan yang membuat mereka saling menghormati dan menghargai. Hasnadi dkk (2012) Mengindentifikasikan bahwa peranan anggota kelompok bukan hanya sekedar teman saja. Juga ditambah lagi dengan keadaan yang tidak mempunyai keluarga lagi sehingga kebutuhan kasih sayangnya sesuai dengan teori kebutuhan Maslow tidak terpenuhi. Happiness adalah dapat berkumpul bersama komunitas Punk. Pernyataan ini juga didukung oleh penelitian sebelumnya oleh (Hansayani \& Hendrijanto, 2013). 
Namun ada beberapa hal yang menjadi catatan penting dari adanya komunitas punk di Banda Aceh. Pertama, pergaulan bebas diantara punkers yang terjadi seperti seks bebas antara laki-laki dan perempuan sehingga melahirkan anak. Merika tidak mau mengasuh dan dibiarkan begitu saja. Anak tersebut kebanyakan dititipkan di panti asuhan Darul As-Sa'dah, Banda Aceh. Kedua, kebanyakan dari mereka menggunakan narkoba dan obat-obatan sejenisnya dalam pergaulannya. Hal ini terjadi saat wawancara. Mereka meminta minuman tuak sebagai syarat agar mereka bersedia untuk diwawancara. Ketiga, dalam Psikologi Islam perilaku mereka merupakan perilaku yang maladaftif dikarenakan ketidakmampuan mereka dalam beradaptasi dengan lingkungan sekitar yang notabennya adalah muslim dan ditambah lagi mereka adalah muslim. Hal tersebut berlawanan dengan visi dan misi Kota Banda Aceh yang menerapkan Syariat Islam sehingga menyebabkan dampak yang berlawanan bagi penerapan syariat Islam di Banda Aceh.

\section{Kesimpulan}

Kebahagiaan dan pemaknaan kehidupan Punkers adalah bahwa berada dalam komunitas ini merupakan suatu hal yang dapat membuat mereka lebih bahagia. Kebahagaiaan bagi mereka dimaknai sebagai kebebasan, harga diri, teman, kekeluargaan, dan traveling. Namun dibalik dari hal tersebut banyak hal penting yang harus menjadi catatan diantaranya pergaulan mereka yang tidak sehat antara sesama, seperti pergaulan bebas, menggunakan narkoba dan pakaian yang tidak sesuai dengan anjuran seorang muslim. Hasil penelitian ini diharapkan dapat sebagai masukan dalam pembinaan remaja punk.

Penelitian ini memiliki beberapa kekurangan yang harus dievaluaasi kedepannya bagi peneliti lainnya. Pertama, dalam proses wawancara yang kurang maksimal karena tempat dan kondisi saat wawancara kurang kondusif akibat kekhawatiran dengan petugas keamanan atau Polisi Pamong Praja sehingga interviewee tidak tenang dalam menjawab wawancara. Kedua, Punk sudah memiliki pengalaman diwawancara oleh peneliti lainnya sebelumnya sehingga data yang diperoleh sulit untuk dipastikan keasliannya. Ketiga, Punk sulit untuk ditemui dan mereka tidak memiliki suatu tempat berkumpul sehingga membuat peneliti kesulitan untuk membuat building rapport.

\section{Daftar Pustaka}

Annisa, A. R., Wibhawa, B., \& Apsari, N. C. (2015). Fenomena Remaja Punk Ditinjau Dari Konsep Person In Environment. 3, 1-154.

Argo, dkk. (2014). "Kebermaknaan Hidup Mantan Punkers". Jurnal. Fakultas Psikologi. Universitas Diponegoro.

Berek.(2014). "Fashion Sebagai Komunikasi Identitas Sub Budaya”. Jurnal. Prodi Magister Ilmu Komunikasi FISIP. Universitas Diponegoro.

Elly, \& Rosana. (2011). Modernisasi dan Perubahan Sosial. 7.

Fariza, T. (2016, November 29). Vice. Retrieved from Vice International: https://www.vice.com/en_asia/article/4xy78q/what-its-like-to-grow-up-in-banda-aceh

Handayani \& Hendrijanto. (2013). "Motivasi Anak Memilih Menjadi Anggota Komunitas Punk". Jurnal. Fakultas Ilmu Sosial dan Ilmu Politik. Jurusan Ilmu Kesejahteraan Sosial. Universitas Jember.

Hasan, E., \& Hamdani, M. (2013, November 2). Perkembangan Komunitas Anak Punk di Kota Banda Aceh.

Hasnadi, dkk. (2012). "Komunitas Punk di Kota Bandung Dalam Memaknai Gaya Hidup". Jurnal.

Fakultas Ilmu Komunikasi. Jurusan Ilmu Managemen. Universitas Padjajaran.

Helmy, Muhammad. (2012). "Public Perception Of Existence Bekonang Punk Community". Jurnal.

Faculty of Teacher Training and Education. University of Surakarta.

Herdiansyah, Haris. (2012). Metodologi Penelitian Kualitatif. Jakarta Selatan: Salemba Humanika.

Kalat, J. (2010). Biopsikologi. Jakarta: Salemba Humanika.

Martin E. P. Seligman, Randal M. Ernst, Jane Gillham, Karen Reivich, Mark Linkins. (2009). Positive education: positive psychology and classroom interventions. Pennsylvania: Oxford Review of Education. 
Petrus, D. I., \& Berek. (2014). Kajian Fenomenologis terhadap Komunitas Street Punk Semarang. Fashion Sebagai Komunikasi Identitas Sub Budaya, 26-66.

Rosana, Ellya. (2011). "Modernisasi Dan Perubahan Sosial". Jurnal. Fakultas Ushuluddin. Prodi pemikiran politik islam IAIN Raden Intan Lampung.

Larsson, M. (2016). Kami Menemui Komunitas Punk yang Diburu di Aceh. [electronic Vertion] Retrieved From https://www.vice.com/id_id/article/mgjpk8/kami-menemui-komunitas-punk-yang-diburu-diaceh

Sari, dkk. (2008). "Identitas Diri Anggota Komunitas Punk di Bandung”. Jurnal. Fakultas Psikologi. Universitas Diponegoro.

Seligman, M. (2009). Authentic Happiness. New York: The Free Press.

Setyad, A. (2017). Tangkap 3 Anak Punk di Aceh, Polisi Berikan [electronic Version]. Retrieved from https://news.detik.com/berita/d-3525274/tangkap-3-anak-punk-di-aceh-polisi-berikanpembinaan-islami

Syam \& Hasan. (2013). "Perkembangan Komunitas Anak Punk Di Kota Banda Aceh" Jurnal. Pendidikan Sains dan Kemanusiaan. 